\title{
Selected issues on political economy, society, and environment of contemporary Vietnam: A preliminary review of the literature
}

\author{
Thu-Trang Vuong \\ Sciences Po Paris, 27 Rue Saint-Guillaume, 75007 Paris, France \\ Email: thutrang.vuong@sciencespo.fr \\ Paris, November 19, 2019 \\ Draft: v.3
}

\section{Overview}

Reviewing works on the history of Vietnamese communism, Bui (1983) commented on the modest amount of French works written on the subject and the diametrically different attitude from American academics. In fact, a large portion of the literature on Vietnam pertained to the Vietnam War and was written from an American perspective. This literature focused on the role of the Vietnam Wars in US history (Beisner 1982; cf. Herring 1986), media (cf. Hallin 1986; Gooch 2009), law and politics (Raskin 1970; Macchiarola 1971; cf. Taylor 1971; cf. Gelb and Betts 1979; Duncanson 1981; Lipsitz 1997; cf.Sturken 1997; Eckhardt 1999; Hagopian 1999; Fried 2014; Kurth 2014) as well as social issues such as mental health and identity (McNamara, et al. 1971; Brodie 1975; Dyer 1990; Wagner-Pacifici and Schwartz 1991; Marmar, et al. 1994). While this topic is not the aim of the review, it is worth mentioning as it is telling of the dominance of the American viewpoint on the subject of Vietnam and, subsequently, of the impression of Vietnam as largely linked to wars as shaped by this dominant viewpoint.

Non-US-centric literature took up a smaller share and generally employed Vietnam as a case study for theories of conflicts, for example (Arreguín-Toft 2001; Norton and Merom 2003). It is also worth noting that the literature on Vietnam - be the focus on the country itself or the Vietnam War - was largely book-based and often ethnographic in nature (cf. Hickey 1964; Louis 1969). More recent works seemed to be less US-centric and more about Vietnam as the subject, perhaps owing to shifts in interest (from attempts to explain and analyze the Vietnam War to a focus on Vietnam's growth, especially economic) as well as to the rise of generations of Vietnamese intellectuals, both contributing to the literature and attracting foreign colleagues towards the country. This literature shall be the focus of the review.

\section{The Party and the regime}

\subsection{Analyses of party history and politics}

Bar the books focusing on the US in which Vietnam War only served as a historical period of interest, number of works tasked themselves with presenting a historical account and providing insights into the workings of the then-newly installed communist regime. One such work was The Communist road 
to power, which gave an exhaustive and intensive look into Vietcong strategies of mass mobilization and the becoming of the Hanoi regime (cf. Duiker 1980; Bain 1982; Joyal 1982).

In a review of four works on the history of the Communist Party, of which two were written by American authors, one by a Vietnamese author, and one an official account published by the Party, Bui (1983) remarked on the reformist and liberal tendencies among authors in the 1980s to document modern Vietnamese political history. He pointed out the lack of historical cover for internal debates in the Communist party at the time. Bui also warned against the langue de bois of the Party's official documents, which shed light on the difficulty of working with a history that is documented by two very polarized sides in terms of ideology: the Communist party on one hand and the anti-communist US-centric works (as presented in the previous section) on the other. The propagandistic tendencies in both language and historiography in the most official documentation (Bui 1983) could turn out to be methodologically problematic if adopted uncritically by the historians themselves, as remarked by Bain (1982).

More recent works have contributed to the intra-party aspect of Vietnamese politics and observed a change in ruling attitude, as the historical legitimacy of the Party wore off with time and with the people's reckoning of the disparity between in-country oppression and liberal societies in the world (Malesky et al. 2011; Malesky 2014). Author Malesky expertly analyzed intra-party politics with appropriate considerations for political combats between individual personalities (such as the purposeful revelation of corruption scandals as an attack against former PM Nguyễn Tấn Dũng at the time) and interactions between entities (Vietnam's National Assembly (VNA) and the Politburo). He also observed the Confidence Vote as one of the indicators of such elite interactions.

\subsection{Structuralist studies and theoretical approach}

Works in comparative politics aimed for generalizations and provide theoretical contributions, using empirical evidence based on the terrain of Vietnam. While the latter was employed as "a laboratory" (Dell et al. 2018) in this current of works, such articles also provided notable insights on the structure of Vietnamese political institutions and its relation with other polities as well as with its own society.

Rose (1998) conducted a case study on the Socialist Republic of Vietnam to analyze the results of legal assistance provided by western liberal democracy with the aim of promoting the "rule of law" in transitional polities. The author reviewed the history of the Vietnamese legal system, from its original Confucian "rule of moral" laws, the struggles between French-imposed legal codes and anti-legalist attitudes from Marxist-Leninist governing actors, to the comfortable settlement of considering the socalled "rule of law" as just another jargon of Party control. In exchange for foreign investment, the government opened the country to legal assistance programs from the multitude of institutional actors involved: organizations (UNDP, ADB, World Bank) and polities (Scandinavian and NorthAmerican countries); as well as private actors (law firms). Drawing on critiques against the Law and Development Movement (LDM) in the US during the 1960s and 1970s, the author characterized the 1990s international legal assistance in Vietnam as part of a "New" LDM and warned against the same risks of ethnocentrism, essentialism, and reinforcement of authoritarian legal structures. The critique read equally as anti-hegemonic and highlights the potential backfiring of foreign intervention in (legal and political) reforms. 
Kerkvliet (2018) analyzed Vietnam in four arenas - governing institutions, media, agricultural collectives, and corruption - to interpret the state-society relations in the authoritarian country. Out of the three dominant interpretations of state-society relations in literature, "state dominance" (in which the state controls the society through state institutions) seemed to take precedence in Vietnam rather than "state corporatism" (in which forces that emerged from society take control of the state and the rest of society using state institutions), at a glance. However, drawing evidence from the emerging power of pressure groups (Buddhist sangha, Chamber of commerce, Women's associations, Peasants' association, etc.), apparent liberalization of the media, public discontent leading to formal abolition of agriculture collectives, social unrest against corruption, Kerkvliet championed the "dialogical" interpretation (in which the society itself finds ways to take control through non-institutional channels) as appropriate to analyze state-society relations in Vietnam. Significant contribution as this was, it is advisable for the author not to overestimate historical evidence of successful voicing of social discontent while casting aside rampant state oppression of popular endeavors.

The historical state, local collective action and economic development in Vietnam (Dell, et al. 2018) adopted a quantitative approach and constructed a model predicting economic outcomes of villages based on its geographical belonging to different historical states which also boasted differing economic organizational structures: the centralized, Sinic, Northeast Asian Dai Viet versus the decentralized, Southeast Asian Khmer. Outcomes were comprised of a wealth of indicators such as years of schooling, road infrastructures, household consumption, health care, and various other indices. Using households in areas that had been converted from the Khmer administrative model to the Dai Viet model at different periods of history since the late $17^{\text {th }}$ century as a natural experiment, the study pointed out the impact of the historical state institutions on economic prosperity (on the unit of villages). It concluded that "areas exposed for a longer period to a strong historical state that implemented institutionalized village government have had better economic outcomes over the past 150 years" - in other words, that Northeast Vietnamese villages were more likely to be prosperous. With this conclusion, the authors highlighted the role of local cooperation that outlives historical institutions, predates contemporary ones. This persisting local cooperation took the stage when the needs for coordination of goods and informal interactions arise in the absence of state and market.

\section{The current economy}

A good part of the peer-reviewed literature was centered on the economy. This is understandable as Vietnam is considered to be an emergent country with an economy in transition - as in, from centrally planned and state-subsidized to free-market - that has been making progress in strides.

\subsection{Macroeconomic analysis and projection}

The literature on macroeconomic workings in Vietnam is ample. Most of them sought to assess the economic results of policy reforms linked to the transition from a command economy to market, such as the introduction of the contract system in 1982, the 1986 Perestroika-esque Đổi Mói reforms, or later legal additions. Pingali and Xuan (1992) provided a comprehensive historical account of the process of collectivization and decollectivization and the mechanisms utilized during each process and affirmed the uplifting effects of policy reforms on rice productivity. In the same vein and with more updated insights, Do, and lyer (2008) studied the effects of the 1993 land laws - which, 
through a program of land-titling and issuance of land-use certificates, secure land rights, and tradability - on rural transitions. While households were slightly more likely to invest in agricultural lands as a result of these reforms, the land laws had virtually no impact on land distribution in Vietnam.

Also taking Đổi Mói policies as the mark, Beresford (2008) evaluated the changes and pointed out how the widely lauded success of the reforms had another side to it: exacerbated inequalities on many counts (rural-urban, regional, sex-based, etc.) and the risk of cronyism. Following the article's conclusion, Beresford suggested the inclusion of all actors into public-private networks in the process of orienting what is to be socialism in Vietnam. In the same spirit of formulating macroeconomic advice, Ohno (2009) conceptualized the catching-up of (mainly) developing nations into five stages of industrialization and pointed out the phenomenon of the middle-income trap in which countries fail to break free of foreign guidance. Ohno suggested the private sector to be the driving force of the Vietnamese economy and industrialization. This, of course, presupposes the convergence model and implies a universalistic view of development.

The work of Miguel and Roland (2011) was arguably one of the most interesting takes among assessments of the post-war, transitional economy of Vietnam. Within the theoretical framework of the poverty trap model, the authors were able to conclude that the US bombing on Vietnam had almost no intra-national effect on the regional economy in the long run while acknowledging that their regression could not account for nationwide effects. The economic catch-up of devastated regions conformed to the neoclassical model of re-stabilization after momentary shock. The author had also considered explaining this absence of long-run economic consequences as being explained, in part, by government efforts of post-war reconstruction. More recently, McCaig and Pavcnik (2013) examined structural shifts in the Vietnamese economy, namely: (1) from agricultural towards more industry and service-based; (2) from household businesses towards the enterprise sectors; and (3) from state-owned enterprises (SOEs) towards private firms. The authors also noted gaps in productivity and labor allocation across and within sectors.

Finally, one must not displace an economy from its regional and global integration, especially not when Vietnam has been making concerted efforts towards international integration ever since the Đối Móri. The economic reform had taken place in conjuncture with joining the Council for Mutual Economic Assistance, joining ASEAN and the ASEAN Free Trade Area (Truong and Gates 1996), and - extendedly - with ascending the WTO in 2009. Economic integration figured among long-term goals as propagated by the government, as was the capturing of foreign development investments (FDI), as evidenced by the 1987 introduction of the Law on Foreign Investment. In overall terms, there was mutual reinforcement between economic growth in Vietnam and FDI, the latter being concentrated in export-oriented manufacturing sectors (Anwar and Nguyen 2010). On a national level, more spending on education and training, as well as on technology and financial market development, would be necessary for the country to benefit from the spillover effect of FDI. On a subnational level, empirical evidence showed that local implementation of national policies was heterogeneous, which created all the variation in FDI attraction and mode of entry across provinces (Meyer and Nguyen 2005).

\subsection{Infra-state microeconomics}


A smaller part of the literature on the Vietnamese economy studied the behavior of individual units (household, village, firm), either with economics or based on economic models (game theory, rational, anticipatory, probabilistic).

Informal interactions and relational agreements, outside of institutionalized structures, often formed the convention of doing business in Vietnam - doing it by "jungle laws" (luật rùng), as it is said in Vietnam. McMillan and Woodruff (1999) made this abundantly clear in a qualitative work featuring mechanisms of informal resolution of contractual disputes between firms, "without the shadow of the law." Repeated-game strategies were relied on as internal motives for cooperation. On the other hand, external constraints were mostly comprised of community sanctions, which related to the importance of local, non-state cooperative governance on the distribution of goods (Dell et al. 2018).

A cross-sectional, experimental study on 9 villages of varying geographical locations and mean income revealed that inhabitants of wealthier villages were less averse to financial risk/loss and more patient (they would accept to wait longer for larger sums of money); people coming from higher-income households were also more patient but showed no significant difference in risk aversion; and everyone showed present bias regardless of income (Tanaka et al. 2010). Interestingly enough, the study found no significant gender difference in risk aversion, which might or might not be linked to Vietnamese specificities.

Bai et al. (2017) developed models aimed to predict the value of bribes (as a share of firm revenue, analogous to taxes in the sense that it is a payment to the government) based on firm growth and mobility. Model testing resulted in empirical evidence suggesting (1) a causal relationship between firm growth and lower corruption and (2) the effect of firm mobility on lower corruption via interprovincial competition to attract or retain mobile firms. The result interpretation read as an optimistic outlook of the potential decline of corruption along with economic growth... provided that these firms neither had nor would seek a place in interest groups related to political figures in power as they grew in size and influence. Another way in which the optimistic outlook could turn wistful was to consider the possibility of corporatism: larger firms, privately owned but linked to powerful figures with intimate relations to the political elite, might buy off smaller firms before they could grow.

\section{Environmental issues}

Suggestion for more dedicated attention towards infrastructure (road, irrigation) and sustainment of environmental qualities (soil, water), all of which are to this day relevant have already been made in earlier works, such as in Pingali and Xuan (1992). The environment is indeed a well-addressed subject in Vietnam, especially in relation to economic growth. The government is aware of the state of pollution in Vietnam and displays advocacy for environmental protection and sustainable development, at least on the surface level.

\subsection{Policy reaction}

Research on environmental concerns seemed to largely focus on the emission of $\mathrm{CO} 2$. More often than not, the theoretical framework evoked the Environmental Kuznets Curve (EKC) hypothesis, according to which $\mathrm{CO} 2$ emissions would increase, plateau, and decrease along with economic growth in an inverse-U curve. This hypothesis had been tested by Al-Mulali et al. (2015) and Tang and Tan (2015) in Vietnam with conflicting results. 
According to Tang and Tan (2015), the EKC hypothesis was verified in Vietnam. Two-way causal links existed between $\mathrm{CO} 2$ emission and income as well as FDI and $\mathrm{CO} 2$ emission, in both short- and longterm. The interplay between income, FDI inflows, and lower $\mathrm{CO} 2$ emissions suggested that higher FDI and subsequently, growth could still improve environmental situations.

Al-Mulali et al. (2015)'s results begged to differ. The investigation focused on other indicators: electricity consumption for growth, for example, and FDI did not figure among the variables, while the labor force, absent from Tang and Tan's research, was taken into account. Their results rejected the EKC hypothesis in Vietnam and corroborated the pollution haven hypothesis, that positive GDP was correlated with higher pollution in the short and long run.

Despite the contradiction, all studies pointed policymakers in the direction of green policies, be it in terms of FDI attraction or GDP boost. Tang et al. (2016) further suggested investment in research and technology development as a more feasible solution to combating climate change, acknowledging the fact that Vietnam remained an energy-dependent country in development that would find it difficult to apply energy conservation policies. The use of renewable was also among the suggestions, although one may wonder about the feasibility of such a measure as well.

Works on reforestation in Vietnam (Meyfroidt and Lambin 2007, 2009) was a different dimension to the environmental question, studying growth based on agricultural productivity rather than from an industrial approach. The observable forest regrowth, both natural and planted, could be attributed to government policies of replanting and increased rice yields on dedicated agricultural lands (which deterred farmers from shifting cultivation on forest plots). However, Meyfroidt and Lambin (2009) also noted the displacement of deforestation to neighboring countries as factoring into reforestation in Vietnam. From a policy point of view, two takeaways from the findings proved to be of interest. One, negotiation at local levels was a more equitable and effective short-term solution to individual forest destruction in areas where farmers still hadn't had access to rice fields; the long-term solution was suggested to be rural depopulation (Meyfroidt and Lambin 2007). Two, observable improvements in environmental conditions in one country might be a displacement of perverse phenomena into other countries.

\subsection{Individual adaptation}

Surveying the hotel industry both by questionnaire and onsite inspection, Trung and Kumar (2005) pinpointed a number of both good and inefficient practices in terms of resource and waste management among hotels. Their findings showed that environment policies mattered just as much on a subnational level, especially considering the high level of informal interactions and the degree to which local implementation of general policies escape from central control (McMillan and Woodruff 1999). This is particularly in services and industries, and more concretely in tourism, given how important the tourism sector is to the Vietnamese economy.

More recent works focused on individual-level adaptations to present and anticipated consequences of climate change. On the preventive aspect, (Clemens et al. 2015) studied the dissemination of knowledge on climate change and adaptation in Vietnam. They tested the theory of social learning using data from Cần Thơ, a southern coastal province, and pinpointed two models of social learning, Collaborative Research, and Learning Alliances. Evidence suggested exclusion of stakeholders, i.e., inhabitants who would possibly be the first to be directly affected by perverse environmental 
changes, from the dialogues, with barriers such as high scientific knowledge. This proves to be especially problematic as it was precisely those excluded population who needed the knowledge and a voice the most. In fact, populations at risk of being affected by climate change were vulnerable on many counts. The negative perception of environmental conditions and anticipation of natural disasters enhanced the likelihood of migration (Koubi et al. 2016), and migrants - especially ruralto-urban - were one of the most financially vulnerable in Vietnam (Vuong 2015).

\section{International relations: then and now}

There were few works concerned with Japanese-Vietnam relations, in whichever language. One such work, Japanese Relations with Vietnam 1954-1987 (cf. Shiraishi 1990; Er 2009; Akaha 2011), examined and described Japanese policies with regards to Vietnam, chronologically. Japan's Vietnam policies fit within the US strategic framework while also concerned with promoting the role of Japan in ASEAN countries. Even this work, however, was written from a Japanese perspective and was more concerned with Japanese intentions in Southeast Asia, and the relationship was perceived from Japan's side.

The body of work on China-Vietnam relations was comparatively wealthier, given that the country had a long history together. As a byproduct of the anti-colonial, pro-dependence campaigns around the August Revolution of 1945 and the two subsequent French and American Wars (the Indochina wars), there was a side of anti-China sentiments due to the fact that nationalist discourses often relied on the history of national heroes, almost all of which had been fighting off Chinese ambitions of domination since a few thousand years B.C. After the American War ended, Saigon fell, and the country of Vietnam was considered reunified, the late 1970s saw several crises between Vietnam and China, in part due to the souring of the relationship between Russia and China. Vietnam's staunch attitude in regards to keeping close ties with Moscow was not appreciated by China; whereas Chinese support of the Pol Pot regime in Cambodia had been met with hostility from the Vietnamese side, especially after Vietnam-Cambodia border disturbances, and ultimately, a war with Cambodia and Vietnamese occupation in Cambodia for the next decade. Sino-Vietnamese tensions culminated into the 1979 (northern) Border War. The relationship took years to normalize (Amer 1994), albeit never without the underlying sentiments of distrust towards China - both the government, mainland Chinese, and ethnic Chinese residing in Vietnam - among Vietnamese people. This low and fragile trust between Vietnam and China further bled into economic and political realms (Vuong et al. 2019b).

\section{Education and health policies}

These two subject matters, education, and health had gathered similar great amounts of attention in the literature on Vietnam as well as a permanent place in public discussions in Vietnam.

\subsection{Education}

The relationship between the economic situation of households and the child's schooling had already been studied by Behrman and Knowles (1999). Taking into account not only a student's completed grades but also total years of schooling versus completed grades - that is, taking into account failed and repeated years, the article had demonstrated a larger effect of household income on child schooling. Results showed that official school fees, which were usually the singular object of 
education-related policies, only accounted for about one-third of the total expenditure on child schooling.

Part of the other two-thirds would perhaps be related to the "shadow" education system explored by Dang (2007) - private tutoring classes outside of the official education system, which required extra tuition fees and was generally organized by individual teachers based on their prestige. The findings shed light on the links between quality of official education as perceived by parents, spending on child's private tutoring, and academic performance. Private tutoring increased the likelihood of higher academic achievements (albeit with diminishing returns), and parents were likely to spend on private tutoring when they believed local schools were not up to the task. This could point to a disparity in spending on education between regions, as well as inequality between students who could afford private tutoring and those who could not. Interestingly, the article also revealed that, contrary to what Behrman and Knowles (1999) had found, there didn't seem to be a gender-based disparity among students themselves in matters of private tutoring. However, the education level of the mother and that of the father affected household spending on private tutoring differently: the mother's influence was significant for primary school pupils, whereas it was that of the father for lower secondary (middle school) students. In short, the phenomenon of private tutoring could be potentially problematic in the sense that it could exacerbate and reproduce inequalities between students with different socio-economic backgrounds.

Another phenomenon linked to education but also largely to other socio-economic issues such as income inequality and poverty was child labor. Rosati and Tzannatos (2006) explored in-depth the phenomenon of child labor in Vietnam, preliminarily remarking that Vietnam had been observably promoting education and literacy and decreasing the proportion of child labor. Results of the study showed that child labor was largely associated with, among others, schooling decisions that took into account household income and schooling costs. The education level of parents was also an important determinant, having a significant effect on reducing the likelihood that a child only worked and never had schooling. Policy implications pointed to reducing the cost of schooling and raising public awareness on the importance of reducing child labor. Policies should also be designed carefully to take into account households which were not eligible for aids solely because they were employing child labor, to incentivize parents to school instead of work their children.

\subsection{Health}

Wagstaff (2007) analyzed how households react to health shocks in Vietnam during the years 19931998. Starting with an informative overview of the health insurance scene in Vietnam, including the official, state-funded health insurance with low coverage and the semi-public and private mutual funds with were limited in both coverage and benefits. Conceptualizing household health shock using three measures - household member death, hospitalization, and BMI drop - the paper studied the effect of health shock on household income and expenditures in new and interesting angles. Health shocks affected household income differently based on the type of health shock and the type of income (earned or unearned). Households also reacted differently in terms of consumption and labor reallocation based on the type of health shock, and household residency (whether they were urban or rural). Notably, results also suggested that even households with health insurance experienced larger spending on medical bills in the face of a health shock. This pointed towards inefficiency in social and health policies to cover people in need. 
In the same vein, a more recent article re-examined the matters of households and health shocks in the period 2004-2008 (Mitra et al. 2016). Health shocks in this article no longer included death or $\mathrm{BMI}$, but was rather focused on time and labor; namely, the measures were days unable to carry out regular activities, days bedridden due to illness/injury, and hospitalization. The study resulted in several key points: health shocks led to large sums of out-of-pocket expenditure, even when consumption was insured; rural and female-led households were the most vulnerable to lack of insurance benefits; and strategies of expenditure reallocation, away from areas such as education and towards medical treatments, were once again observed. It was worth noting the disparity between rural and urban patients, that would be made clearer in Vuong (2015).

The issue of national health insurance in Vietnam, or the inadequacy thereof, was further examined in Vuong (2015) using a cross-sectional dataset gathered through the survey and personal interviews conducted by the author and assistants themselves. The paper analyzed the current health insurance scheme, which was heavily based on patient residence in its determination of coverage and benefits. On the other hand, the current infrastructure of the health care system often did not meet the needs of people in rural areas, prompting them to seek out facilities in larger cities when in need of serious treatment. This necessarily entailed lower insurance benefits or even none at all, putting non-residency patients in large cities in a very vulnerable position with a high risk of destitution due to medical bills, with or without insurance. As it appeared, in the time-lapse between Vuong (2015) whose survey was conducted after 2010, Mitra et al.'s (2016) analysis on the 20042008 period and Wagstaff's (2007) study on the 1993-1998 period, the government had done little to improve health policies in favor of economically vulnerable groups. Households still had to rely on coping strategies such as expenditure reallocation that might affect future welfare, and even then, they were still at risk of going bankrupt.

Tran et al. (2016) posed a more specific question: the health of minority ethnic groups in remote and mountainous areas in Northern Vietnam - a population that could be seen as vulnerable or selfsufficient depending on how discourses were framed, due to the fact that they were remote and often functioned as closed-off societies (in small units, such as villages) with their structure of organization. As it turned out, interestingly, Muong people, one of the larger ethnic minority groups, had even easier access than the majority ethnic Kinh of Vietnam, but more difficult access to traditional medicine. Nevertheless, the results suggested that in general, these minority groups often lacked the means to access conventional health care provided by the public system, they were faced with a little obstacle to access traditional medicine.

The fact that minority ethnic groups were more likely to resort to traditional medicine instead of seeking out doctors at community health centers, despite government initiatives to encourage them to, would tie in with several other characteristics of remote, minority ethnic groups that might be linked to their poverty status. This, and more shall be addressed in the next section.

\section{The socio-economic dynamics of income inequalities}

\subsection{Ethnic minorities}

Van de Walle and Gunewardena (2001) started their examination of ethnic minority groups and their behavior in relation to poverty by looking at the general perception by Kinh bureaucrats of these groups, pointing out that the largely Kinh officials tended to explain failures of government 
development programs was due to these populations' own resistance, stemming from ignorance or irrationality; while it could be argued that the failure might have been because the development models applied in such programs had been incompatible with the circumstances of minority groups. Results pointed to very complex relationships between geographic and characteristic variables of each group; as such, one should approach ethnic minority communities and ethnic majority (Kinh) communities using fundamentally different models of income generation.

Studying Programs 132 and 134 - governmental programs of land distribution targeting ethnic minority households in the provinces in the Central Highlands of Vietnam - Benjamin et al. (2018) posed the question: whether ethnic minorities truly benefitted from these reform programs, in terms of household income. The data showed that not only did their income not increase from having agricultural land allocated to them, but certain households even lost sideline income - coming from perennial trees - due to having forest land taken away from them in exchange. This corroborated with findings in van de Walle and Gunewardena (2001): without bearing in mind the varying differences between ethnic groups and the different models of income generations they engendered, programs combatting poverty in ethnic minority-concentrated areas would continue to be ineffectual, and inequality between ethnic minorities and the Kinh majority would remain.

\subsection{The rural-urban gap}

Affirming that the urban-rural gap was particularly pronounced in Vietnam and thus particularly interesting to study, Nguyen et al. (2007) focused on the welfare inequality between rural and urban households and examined as determinants certain characteristics - namely, education, ethnicity, and engagement in agriculture - as well as returns to those characteristics. The authors suggested that for the poor, they were worse off due to the rural-urban difference in characteristics, whereas better-off households were rewarded by the difference in returns of those characteristics. These results supported conventional policy approaches to poverty and inequality reduction, especially the inclusion of education and employment opportunities for the poor, as well as the enhancement of flexibility on the labor market, i.e., improving infrastructures and workers' mobility between regions. It should also be noted that a characteristic of rural Vietnam that both set it apart from urban areas and punished rural households was its exposure to natural disasters (Arouri et al. 2015).

The characteristic difference between rural and urban areas, as well as the income and welfare disparities between households from these areas, often prompted migration - primarily from rural to urban. The effect of this phenomenon on individual households, in terms of vulnerability and welfare, was investigated by Nguyen et al. (2015), on a sample of three provinces - Đák Lák, Thừa Thiên Huế, and Hà Tinh - in Vietnam. The study pointed out that migration was for employment or education, with migration for employment having far many more significant determinants, such as the age of household head, number of dependent members in the household, localization, etc. Men were more likely to work in the service sector (as a security guard, salesperson, technician, etc.), whereas women were more likely to work in factories, mainly textiles. Results also showed that migration had no effect on household vulnerability, but could help a rural household move out of poverty. This was simultaneously a suggestion and a warning to policy-makers: on one hand, it might suggest a way to target-reduce poverty rates in rural areas; on the other, it was symptomatic of the gaping inequality between rural and urban households as well as the personal strategies that rural inhabitants must make in order to better their own life, in the absence of effective help from the government. 


\subsection{Poverty and beyond}

Imai et al. (2011) measured vulnerability as expected poverty and examined vulnerability and poverty, in terms of household consumption/expenditure rather than income. Findings suggested that vulnerability not only translated into poverty over time but also propelled non-poor households into poverty and was likely to generate poverty traps. Determinants of vulnerability included but were not limited to landlessness and lack of education, and also certain characteristics specific to ethnic minorities such as different attitudes to risks and insurance. This might account for the relatively unchanged spatial contour of poverty in Vietnam despite accelerated growth in the years following 1986: geographical areas in which more ethnic minorities were concentrated, such as remote regions in the Northern mountains or the Central Highlands, were often poorer than the rest.

$\mathrm{Vu}$ and Glewwe (2011) showed complex outcomes of rising food prices on household welfare and poverty rates: namely, that while average household welfare increased, so did national poverty. The answer lied in polarization: the rise in welfare among net sellers - those who gained from food price hikes - offset the loss of welfare, among others. The results also showed that urban poverty was more likely to rise in the face of increasing food prices, given the fact that rural households were more often net sellers of foodstuff. That being said, even in rural areas, it was the middle-income households that gained; the poorest households were faced with the highest loss. Besides, different regions would be hit differently by rising food prices - namely, the Southeast region and the Central Highlands were hit the hardest in terms of falling welfare. In short, the findings suggested policymaker to target the poorest quintiles in regulating prices or subsidies, and also taking into account regional differences in implementing such policies.

In the same vein, Benjamin et al. (2017) recognized the reduction in the poverty rate in Vietnam since before the year 2000, which slowed down in the mid-2000s, and once again remarked that the poorest households resided in the countryside, and persistent poverty remained most prevalent among ethnic minorities. As such, as income rose, income inequality persisted. Using household per capita income as the dependent variable of interest, the study delved into trends of inequality in the period 2002-2004 in Vietnam. The effect of polarization could be once more observed; while the general rate of poverty was reduced, inequality increased among poorer households between 2002 and 2014. The article also remarked that the rural-urban gap had shrunken. Inequality was becoming increasingly an intra-category outcome: within a location (rural or urban) and among minority ethnic groups.

In one word, ethnic minority, rural-urban residence, and geographic region were the most often highlighted factors in analyses of poverty and income inequality. Additionally, many of the studies mentioned in this section utilized the Vietnam Household Living Standard Survey (VHLSS), which provided a nationally representative sample. This pointed towards the use of the VHLSS sample as tried and tested, a solid choice of the dataset for future research; at the same time, one should be aware of limitations that the dataset might pose.

\section{Precariousness and women's rights}

One may observe an absence of gender-based differences in certain issues such as child labor (Rosati and Tzannatos 2006) and regional migration decisions (Nguyen et al. 2015). This should not 
distract one from the fact that women were still often found to be at a higher risk of vulnerability and discrimination in many other social and societal issues.

\subsection{Risks: financial and health}

In the labor market, women as a whole usually found themselves at a disadvantage. Women were usually paid lower salaries than men (Nguyen et al. 2015). When faced with shocks, such as when state enterprises were liquidated as a result of poor performance, the majority of laid-off workers turned out to be women (Beresford 2008). Beresford (2008) also underlined the fact that women, especially rural women, were "the most vulnerable to persistent poverty." They bore the major workload in informal, unpaid domestic sectors, yet were a diminishing minority in formal sectors, which often rendered them financially dependent and vulnerable. This also reinforced their lack of agency stemming from traditional gender roles. Klasen et al. (2015), however, pointed out that female-headed households were not necessarily worse off than male-headed ones, largely due to the heterogeneity among female-headed households, which were subsequently grouped into de jure (divorcees or widows) and de facto female heads of households. Towards the end, the authors suggested that worse off households might have been vulnerable by being single-headed rather than due to gender differences in household heads. This being said, the hypothesis was not yet tested ceteris paribus between male and female household heads.

Not only did women face disproportionate labor insecurity, but they also suffer from health risks. Discussing health in the context of HIV prevention, Nguyen et al. (2008) assessed that HIV risks among women had been underestimated, firstly due to a great number of women already afflicted with HIV being invisible in official statistics. The government thus targeted mainly injected-drug users (IDU) - who were also much more often males - in HIV prevention initiatives, while paying less consideration to female sex workers (FSW), who might also be IDU in certain cases. Suggestions include increase detection of afflicted female individuals, raise awareness of STD and promote safe sex, and a refocus of high-risk populations, from targeting IDU primarily to including FSW as well. On the issue of mental health, Tran et al. (2016) showed that there was a prevalence of depression and other psychiatric issues among women, more so than men, among ethnic minority groups in remote and mountainous regions in Northern Vietnam.

\subsection{Reproduction of inequality}

Gender norms imposed on Vietnamese women were a superposition of the traditional Confucian model and the Socialist model, which influenced not only informal social interactions but also criteria recognized by the Vietnam Women's Union (VWU) (Schuler et al. 2006). Women were supposed to put the family's and the nation's interests above her own. Schuler et al. 's qualitative study evidenced, among others, official endorsements that could prove to be harmful to women: namely, victim-blaming mentality (even if a woman is beaten by her husband, she would still be considered lacking because "should have the skills to persuade [influence] her husband and make the family harmonious"); and the double responsibility as shown in the slogan giỏi việc nước, đảm việc nhà ("good at national tasks, good at household task"). There was a consensus among respondents that wives should be encouraged to participate in civic activities organized by the VWU, but only when such activities would not compromise the completion of household duties. The interviewed women also agreed that they should be deferent and should not have too much career ambitions, so as not 
to challenge traditional family hierarchies. In trying to resolve the contradiction between the Socialist promotion of gender equality and the Confucian idea of female obedience, national policies, as represented by VWU-led campaigns, actively encouraged outdated and harmful female gender roles to reproduce.

One of the Confucian legacies that were rather observable in Vietnam, at least up until recently, was son preference, especially in rural areas. Guilmoto (2012) examined this aspect in conjunction with patrilineal household structures, similar to China, which considered the male lines to be the "inside family" (hence the terms ông bà nội, literally "inside grandparents", employed to refer to paternal grandparents; and, correspondingly, ông bà ngoại ("outside grandparents") to refer to the maternal side). Son preference and the doting on male heirs could lead to certain household choices to the disadvantage of the female when the household was under financial constraints; for example, the schooling of girls was considered to be more of luxury while schooling boys was a necessity (Behrman and Knowles 1999). This overt yet culturally favored discrimination would further perpetuate the vicious cycle of female subordination and female-negative stereotypes, making it harder for women to break out of it.

\section{Culture, arts, and religion}

Vuong et al. (2018) investigated Vietnamese folktales to elaborate on the theory and notion of cultural additivity, the mechanism through which the cultural aspects built around each of the three main religions of Vietnam - Confucianism, Buddhism, and Taoism - interacted in the folkloric mentality. Aside from confirming the preponderance of Confucianism in the culture of Vietnam, the study also contributed to the literature on the interaction and exchange of cultures.

Inscribed in the current of research on cultural evolution, Vuong et al. (2019a) focused on the hybrid influence of French colonization and present Chinese cultural presence on Vietnamese architecture by studying the façade of 68 houses dating back to the colonized era in the Old Quarters of Hanoi. Architectural details were conceptualized and entered as text data to be later analyzed using Bayesian statistics. The article recognized three types of house facades based on the amount of French influence to be found in it, from which three stages of the cultural evolution of those houses were theorized. Other than its contribution to the literature on cultural evolution, the study also shed more light on the various aspects through which French culture had influenced Vietnamese culture, and how the legacy of French colonization remained imbued in Vietnam to this day.

\section{References}

Akaha, Tsuneo. 2011. "Japanese Relations with Vietnam: 1951-1987. By Masaya Shiraishi. Ithaca: Cornell University Southeast Asia Program, 1990. Ix, 164 Pp. \$12.00." The Journal of Asian Studies 50: 467-69.

Al-Mulali, Usama, Behnaz Saboori, and Ilhan Ozturk. 2015. "Investigating the Environmental Kuznets Curve Hypothesis in Vietnam." Energy Policy 76: 123-31.

Amer, Ramses. 1994. "Sino-Vietnamese Normalization in the Light of the Crisis of the Late 1970s." Pacific Affairs 67: 357-83.

Anwar, Sajid, and Lan Phi Nguyen. 2010. "Foreign Direct Investment and Economic Growth in Vietnam." Asia Pacific Business Review 16: 183-202.

Arouri, Mohamed, Cuong Nguyen, and Adel Ben Youssef. 2015. "Natural Disasters, Household Welfare, and Resilience: Evidence from Rural Vietnam." World Development 70: 59-77. 
Arreguín-Toft, Ivan. 2001. "How the Weak Win Wars: A Theory of Asymmetric Conflict." International Security 26: 93-128.

Bai, Jie, Seema Jayachandran, Edmund J. Malesky, and Benjamin A. Olken. 2017. "Firm Growth and Corruption: Empirical Evidence from Vietnam." Economic Journal 0.

Bain, Chester A. 1982. "William J. Duiker. The Communist Road to Power in Vietnam. (Westview Special Studies on South and Southeast Asia.) Boulder, Colo.: Westview Press. 1981.". The American Historical Review 87: 1148-48.

Behrman, Jere R., and James C. Knowles. 1999. "Household Income and Child Schooling in Vietnam." The World Bank Economic Review 13: 211-56.

Benjamin, Dwayne, Loren Brandt, and Brian McCaig. 2017. "Growth with Equity: Income Inequality in Vietnam, 2002-14." Journal of Economic Inequality 15: 25-46.

Benjamin, Dwayne, Loren Brandt, Brian McCaig, and Hoa Nguyen Le. 2018. "Program Participation in a Targeted Land Distribution Program and Household Outcomes: Evidence from Vietnam." Review of Economics of the Household 16: 41-74.

Beresford, Melanie. 2008. "Doi Moi in Review: The Challenges of Building Market Socialism in Vietnam." Journal of Contemporary Asia 38: 221-43.

Brodie, Bernard. 1975. "Home from the War: Vietnam Veterans, Neither Victims nor Executioners." Review of Home from the War: Vietnam Veterans, Neither Victims nor Executioners, Robert Jay Lifton. The Journal of Interdisciplinary History 5: 772-73.

Bui, Xuan Quang. 1983. "Robert F. Turner. Vietnamese Communism. Its Origins and Development. William J. Duiker. The Communist Road to Power in Vietnam. Huynh Kim Khanh. Vietnamese Communism 1925-1945. Lịch Sử Đảng Cộng Sản Việt Nam: Trích Văn Kiện Đảng." Politique étrangère: 502-04.

Clemens, Maria, Jeroen Rijke, Assela Pathirana, Jaap Evers, and Nguyen Hong Quan. 2015. "Social Learning for Adaptation to Climate Change in Developing Countries: Insights from Vietnam." Journal of Water and Climate Change 7: 365-78.

Dang, Hai-Anh. 2007. "The Determinants and Impact of Private Tutoring Classes in Vietnam." Economics of Education Review 26: 683-98.

Dell, Melissa, Nathan Lane, and Pablo Querubin. 2018. "The Historical State, Local Collective Action, and Economic Development in Vietnam." Econometrica 86: 2083-121.

Do, Quy-Toan, and Lakshmi lyer. 2008. "Land Titling and Rural Transition in Vietnam." Economic Development and Cultural Change 56: 531-79.

Duiker, William J. 1980. The Communist Road to Power in Vietnam. 2nd ed. ed. XVI-435 p. : cartes; $24 \mathrm{~cm}$ vols. Boulder, Colo.: Westview.

Duncanson, Dennis. 1981. "The Irony of Vietnam: The System Worked." Review of The Irony of Vietnam: The System Worked, Leslie H. Gelb, Richard K. Betts; Back to the Front: The Unfinished Story in Vietnam, R. P. Kaushik, S. Kaushik. Third World Quarterly 3: 363-64.

Dyer, Carolyn Stewart. 1990. "The Remasculinization of America: Gender and the Vietnam War." American Journalism 7: 206-07.

Eckhardt, William George. 1999. "My Lai: An American Tragedy Essays on the Trials of the Century." UMKC Law Review: 671-704.

Er, Lam Peng. 2009. "Vietnam - Japanese Relations with Vietnam: 1951-1987. By Masaya Shiraishi. Ithaca, New York: Southeast Asia Program, Cornell University, 1990. Pp. Ix; 164. Tables, Charts, Abbreviations, Bibliography, Glossary." Journal of Southeast Asian Studies 25: 225-27.

Fried, John H. E. 2014. "Nuremberg and Vietnam: An American Tragedy. By Telford Taylor. (Chicago: Quadrangle Books [a New York Times Book], 1970. Pp. 207. \$5.95, Cloth; \$1.95, Paper.)." American Political Science Review 65: 1257-58.

Gelb, Leslie H., and Richard K. Betts. 1979. The Irony of Vietnam: The System Worked Edited by Richard K. Betts. Second edition ed. 1 vol. (XI-387 p.). Washington: Brookings Institution. 
Gooch, John. 2009. "Daniel C. Hallin, the "Uncensored War": The Media and Vietnam (Oxford: Oxford University Press, 1986, £18.00). Pp. 285. Isbn 019503814 2." Journal of American Studies 21: 475-76.

Guilmoto, Christophe Z. 2012. "Son Preference, Sex Selection, and Kinship in Vietnam." Population \& Development Review 38: 31-54.

Hagopian, Patrick. 1999. "Tangled Memories: The Vietnam War, the Aids Epidemic, and the

Politics of Remembering by Marita Sturken." Review of Tangled Memories: The Vietnam War, the AIDS Epidemic, and the Politics of Remembering, Marita Sturken. The Public Historian 21: 108-10.

Hallin, Daniel C. 1986. The Uncensored War: The Media and Vietnam. VIII-285 p. New York: Oxford University Press.

Hickey, Gerald Cannon. 1964. "Village in Vietnam." American Behavioral Scientist 8: 27-29.

Imai, KatsushiS, Raghav Gaiha, and Woojin Kang. 2011. "Vulnerability and Poverty Dynamics in Vietnam." Applied Economics 43: 3603-18.

Joyal, André. 1982. "Duiker, William J. The Communist Road to Power in Vietnam. Boulder (Col.), Westview Press, 1980, 411 P." Études Internationales 13: 773-75.

Kerkvliet, Benedict J. Tria. 2018. "An Approach for Analysing State-Society Relations in Vietnam." SOJOURN: Journal of Social Issues in Southeast Asia 33: S156-S98.

Klasen, Stephan, Tobias Lechtenfeld, and Felix Povel. 2015. "A Feminization of Vulnerability? Female Headship, Poverty, and Vulnerability in Thailand and Vietnam." World Development 71: 36-53.

Koubi, Vally, Gabriele Spilker, Lena Schaffer, and Thomas Bernauer. 2016. "Environmental Stressors and Migration: Evidence from Vietnam." World Development 79: 197-210.

Kurth, James R. 2014. "The Irony of Vietnam: The System Worked. By Leslie H. Gelb, with Richard K. Betts. (Washington, D.C.: The Brookings Institution, 1979. Pp. Viii + 387. \$14.95, Cloth; \$5.95, Paper.)." American Political Science Review 75: 196-98.

Lipsitz, George. 1997. "Tangled Memories: The Vietnam War, the Aids Epidemic, and the Politics of Remembering (Book)." American Journal of Sociology 103: 796-98.

Louis, Nicole. 1969. "Gerald Cannon Hickey : Village in Vietnam." Bulletin de l'École française d'Extrême-Orient: 195-99.

Macchiarola, Frank J. 1971. "Nuremberg and Vietnam: An American Tragedy." Review of Nuremberg and Vietnam: An American Tragedy, Telford Taylor. Columbia Law Review 71: 950-60.

Malesky, Edmund. 2014. "Vietnam in 2013Single-Party Politics in the Internet Age." Asian Survey 54: 30-38.

Malesky, Edmund, Paul Schuler, and Anh Tran. 2011. "Vietnam Familiar Patterns and New Developments Ahead of the 11th Party Congress." Southeast Asian Affairs: 339-63.

Marmar, Charles R., Daniel S. Weiss, William E. Schlenger, John A. Fairbank, B. Kathleen Jordan, Richard A. Kulka, and Richard L. Hough. 1994. "Peritraumatic Dissociation and Posttraumatic Stress in Male Vietnam Theater Veterans." The American Journal of Psychiatry 151: 902-07.

McCaig, Brian, and Nina Pavcnik. 2013. "Moving out of Agriculture: Structural Change in Vietnam." National Bureau of Economic Research Working Paper Series No. 19616.

McMillan, John, and Christopher Woodruff. 1999. "Dispute Prevention without Courts in Vietnam." Journal of Law, Economics, \& Organization 15: 637-58.

McNamara, J. Judson, Mark A. Molot, John F. Stremple, and Robert T. Cutting. 1971. "Coronary Artery Disease in Combat Casualties in Vietnam." JAMA 216: 1185-87.

Meyer, Klaus E., and Hung Vo Nguyen. 2005. "Foreign Investment Strategies and Sub-National Institutions in Emerging Markets: Evidence from Vietnam*." Journal of Management Studies 42: 63-93. 
Meyfroidt, Patrick, and Eric F. Lambin. 2007. "The Causes of the Reforestation in Vietnam." Land Use Policy 25: 182-97.

2009. "Forest Transition in Vietnam and Displacement of Deforestation Abroad." Proceedings of the National Academy of Sciences 106: 16139.

Miguel, Edward, and Gérard Roland. 2011. "The Long-Run Impact of Bombing Vietnam." Journal of Development Economics 96: 1-15.

Mitra, Sophie, Michael Palmer, Daniel Mont, and Nora Groce. 2016. "Can Households Cope with Health Shocks in Vietnam?". Health Economics 25: 888-907.

Napier, Nancy K., and Vuong Quan Hoang. 2013. What we see, why we worry, why we hope: Vietnam going forward. Boise ID, USA: Boise State University CCI Press.

Nguyen, Binh T., James W. Albrecht, Susan B. Vroman, and M. Daniel Westbrook. 2007. "A Quantile Regression Decomposition of Urban-Rural Inequality in Vietnam." Journal of Development Economics 83: 466-90.

Nguyen, Loc Duc, Katharina Raabe, and Ulrike Grote. 2015. "Rural-Urban Migration, Household Vulnerability, and Welfare in Vietnam." World Development 71: 79-93.

Nguyen, Thu Anh, Pauline Oosterhoff, Anita Hardon, Hien Nguyen Tran, Roel A. Coutinho, and Pamela Wright. 2008. "A Hidden Hiv Epidemic among Women in Vietnam." BMC Public Health 8: 37.

Norton, Richard, and Gil Merom. 2003. How Democracies Lose Small Wars: State, Society, and the Failures of France in Algeria, Israel in Lebanon, and the United States in Vietnam. Cambridge: Cambridge University Press.

Ohno, Kenichi. 2009. "Avoiding the Middle-Income Trap." ASEAN Economic Bulletin 26: 25-43.

Pingali, Prabhu L., and Vo-Tong Xuan. 1992. "Vietnam: Decollectivization and Rice Productivity Growth." Economic Development and Cultural Change 40: 697-718.

Raskin, Marcus G. 1970. "Nuremberg and Vietnam: An American Tragedy, by Taylor Telford." Yale Review of Law and Social Action: 92-96.

Rosati, Furio Camillo, and Zafiris Tzannatos. 2006. "Child Labour in Vietnam." Pacific Economic Review 11: 1-31.

Rose, Carol V. 1998. "The "New" Law and Development Movement in the Post-Cold War Era: A Vietnam Case Study." Law \& Society Review 32: 93-140.

Schuler, Sidney Ruth, Anh Hoang Tu, Ha Vu Song, Minh Tran Hung, Mai Bui Thi Thanh, and Thien Pham Vu. 2006. "Constructions of Gender in Vietnam: In Pursuit of the 'Three Criteria'." Culture, Health \& Sexuality 8: 383-94.

Shiraishi, Masaya. 1990. Japanese Relations with Vietnam: 1951-1987. IX-164 p. ; 26 cm vols, Southeast Asia Program Series. Ithaca, N.Y.: Cornell University, Southeast Asia Program.

Sturken, Marita. 1997. Tangled Memories: The Vietnam War, the Aids Epidemic, and the Politics of Remembering: The Vietnam War, the Aids Epidemic, and the Politics of Remembering. X358 p. : ill. ; $23 \mathrm{~cm}$ vols. Berkeley, Calif.: University of California Press.

Tanaka, Tomomi, Colin F. Camerer, and Quang Nguyen. 2010. "Risk and Time Preferences: Linking Experimental and Household Survey Data from Vietnam." American Economic Review 100: 557-71.

Tang, Chor Foon, and Bee Wah Tan. 2015. "The Impact of Energy Consumption, Income and Foreign Direct Investment on Carbon Dioxide Emissions in Vietnam." Energy 79: 447-54.

Tang, Chor Foon, Bee Wah Tan, and Ilhan Ozturk. 2016. "Energy Consumption and Economic Growth in Vietnam." Renewable and Sustainable Energy Reviews 54: 1506-14.

Taylor, Telford. 1971. Nuremberg and Vietnam: An American Tragedy. New York: Bantam Books.

Tran, Bach Xuan, Long Hoang Nguyen, Vuong Minh Nong, and Cuong Tat Nguyen. 2016. "Health Status and Health Service Utilization in Remote and Mountainous Areas in Vietnam." Health and Quality of Life Outcomes 14: 85.

Trung, Do Nam, and S. Kumar. 2005. "Resource Use and Waste Management in Vietnam Hotel Industry." Journal of Cleaner Production 13: 109-16. 
Truong, David H. D., and Carolyn L. Gates. 1996. "Vietnam in Asean-Economic Reform, Openness, and Transformation." ASEAN Economic Bulletin 13: 159.

Van de Walle, Dominique, and Dileni Gunewardena. 2001. "Sources of Ethnic Inequality in Viet Nam." Journal of Development Economics 65: 177-207.

Vu, Linh, and Paul Glewwe. 2011. "Impacts of Rising Food Prices on Poverty and Welfare in Vietnam." Journal of Agricultural and Resource Economics 36: 14-27.

Vuong, Quan-Hoang. 2015. "Be Rich or Don't Be Sick: Estimating Vietnamese Patients' Risk of Falling into Destitution." SpringerPlus 4: 529.

Vuong, Quan-Hoang, Quang-Khiem Bui, Viet-Phuong La, Thu-Trang Vuong, Manh-Toan Ho, Hong-Kong T. Nguyen, Hong-Ngoc Nguyen, Kien-Cuong P. Nghiem, and Manh-Tung Ho. 2019a. "Cultural Evolution in Vietnam's Early 20th Century: A Bayesian Networks Analysis of Hanoi FrancoChinese House Designs." Social Sciences \& Humanities Open 1: 100001.

Vuong, Quan-Hoang, Quang-Khiem Bui, Viet-Phuong La, Thu-Trang Vuong, Viet-Ha T. Nguyen, ManhToan Ho, Hong-Kong T. Nguyen, and Manh-Tung Ho. 2018. "Cultural Additivity: Behavioural Insights from the Interaction of Confucianism, Buddhism, and Taoism in Folktales." Palgrave Communications 4: 143.

Vuong, Quan-Hoang, Thu-Trang Vuong, Manh-Tung Ho, and Hong-Kong T. Nguyen. 2019b. "The 'Same Bed, Different Dreams' of Vietnam and China." European Journal of East Asian Studies 18: 93-128.

Vuong, Quan-Hoang, and Tran Trung. 2019. The Vietnamese Social Sciences at a Fork in the Road. Warsaw, Poland: De Gruyter. DOI: 10.2478/9783110686081-014.

Wagner-Pacifici, Robin, and Barry Schwartz. 1991. "The Vietnam Veterans Memorial: Commemorating a Difficult Past." American Journal of Sociology 97: 376-420.

Wagstaff, Adam. 2007. "The Economic Consequences of Health Shocks: Evidence from Vietnam." Journal of Health Economics 26: 82-100. 